\title{
Jacobsen Syndrome: Surgical Complications due to Unsuspected Diagnosis, the Importance of Molecular Studies in Patients with Craniosynostosis
}

\author{
Etzalli P. Linares Chávez ${ }^{a} \quad$ Jaime Toral López ${ }^{c}$ Juan M. Valdés Miranda ${ }^{a}$ \\ Luz M. González Huerta ${ }^{a}$ Adrian Perez Cabrera ${ }^{a}$ María del Refugio Rivera Vega ${ }^{a}$ \\ Olga M. Messina Baas ${ }^{b}$ Sergio A. Cuevas-Covarrubias ${ }^{a}$ \\ Departamentos de a Genética Médica and b Oftalmología, Hospital General de México, Facultad de Medicina, Universidad \\ Nacional Autónoma de México (UNAM), Mexico City, and ' $D$ Departamento de Genética Médica, Centro Médico Ecatepec, \\ ISSEMYM, Edomex México, México
}

\section{Key Words}

Craniosynostosis · CytoScan HD array · Deletion 11q ·

Intellectual disability

\begin{abstract}
Jacobsen syndrome (JBS) is an uncommon contiguous gene syndrome. About $85-92 \%$ of cases have a de novo origin. Clinical variability and severity probably depend on the size of the affected region. The typical clinical features in JBS include intellectual disability, growth retardation, craniofacial dysmorphism as well as craniosynostosis, congenital heart disease, and platelet abnormalities. The proband was a 1 year/3-month-old Mexican male. Oligonucleotide-SNP array analysis using the GeneChip Human Cytoscan HD was carried out for the patient from genomic DNA. The SNP array showed a 14.2-Mb deletion in chromosome 11q23.3q25 (120,706-134,938 Mb), which involved 163 RefSeq genes in the database of genomic variation. We report a novel deletion in JBS that increases the knowledge of the variability in the mutation sites in this region and expands the spectrum of molecular and clinical defects in this syndrome.
\end{abstract}

(c) 2015 S. Karger AG, Basel (c) 2015 S. Karger AG, Basel

$1661-8769 / 15 / 0065-0229 \$ 39.50 / 0$
Jacobsen syndrome (JBS; OMIM 147791), also known as terminal 11q23.3q25 deletion, is an uncommon contiguous gene syndrome with about 200 cases reported worldwide. JBS has a prevalence of 1 in 100,000 newborns with a female predominance of 2:1 [So et al., 2014]. About $8-15 \%$ of cases are caused by a deletion from a parental balanced chromosome translocation or other rearrangements, whereas $85-92 \%$ have a de novo origin [Grossfeld et al., 2004; Van Zutven et al., 2009]. Clinical variability and severity depend on the size and the location of the deleted region. The typical clinical features in JBS include intellectual disability (97\%), growth retardation (68-75\%), craniofacial dysmorphism (>40\%), congenital cardiac malformations (56\%), and platelet abnormalities (88.5-94\%). Kidney (8-13\%), gastrointestinal (18\%), genitalia (36-60\%), and brain (51-65\%) defects, as well as skeletal dysplasia (14\%) can also be present. Behavioral and psychiatric disorders, hearing, immunological and hormonal problems have also been observed [Grossfeld et al., 2004; Manolakos et al., 2009; Mattina et al., 2009; Seppänen et al., 2014; Akshoomoff et al., 2015; Favier et al., 2015]. Several patients with

\section{KARGER 125}

E-Mail karger@karger.com

www.karger.com/msy
Dr. Sergio A. Cuevas-Covarrubias

Departamento de Genética Médica, Hospital General de México

Dr. Balmis 148 Col Doctores

Mexico City 06726 (Mexico)

E-Mail sergioa@ servidor.unam.mx 

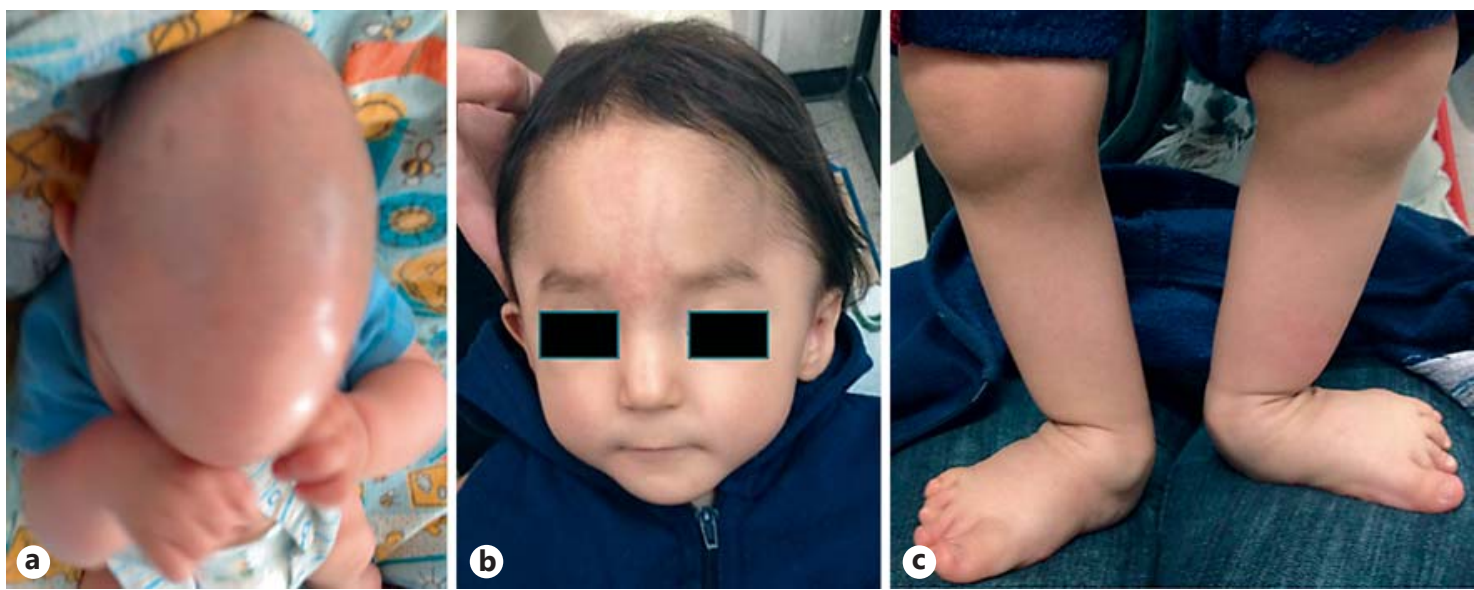

Fig. 1. Features of the patient. a Patient at the age of 6 months. b, $\mathbf{c}$ Patient at the age of 1 year and 3 months.
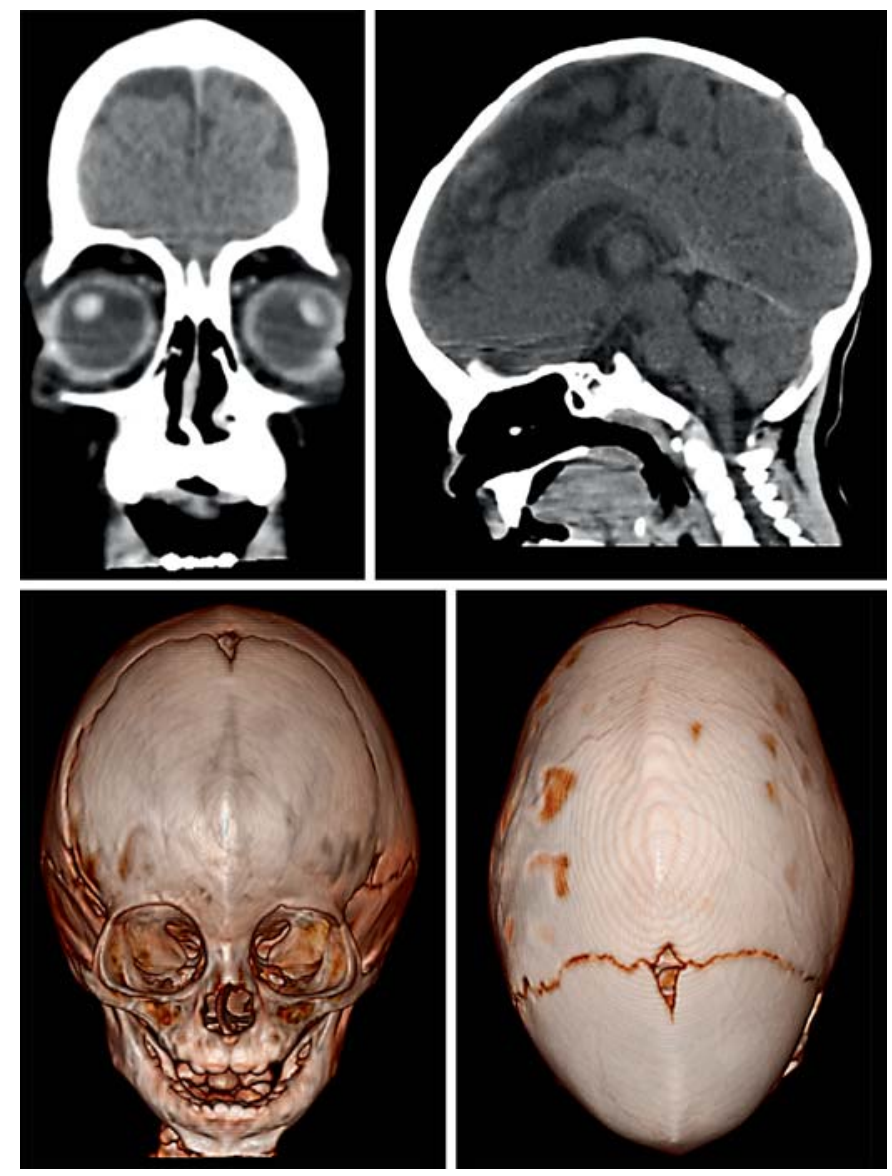

Fig. 2. CT of the brain. Cortico-subcortical atrophy, sagittal and metopic synostosis are observed.
$11 \mathrm{q} 23.3 \mathrm{q} 25$ deletions ranging in size from 2.8 to $14 \mathrm{Mb}$ revealed by molecular karyotyping have been reported, but only 17 patients have complete clinical data [Wenger et al., 2006; Bernaciak et al., 2008; Tyson et al., 2008; Manolakos et al., 2009; Ji et al., 2010; Wu et al., 2010; Ye et al., 2010; Guerin et al., 2012, Trkova et al., 2012; Sheth et al., 2014; So et al., 2014; Xu et al., 2014; Malia et al., 2015; Maruani et al., 2015; Yamamoto et al., 2015]. The purpose of this study is to report the SNP microarraybased molecular characterization of a patient with a mild phenotype of JBS and a 11q23.3q25 deletion. We compared previous cases with molecular karyotyping and found that genotype-phenotype correlation was not present. This study also highlights the surgical complications due to unsuspected diagnosis and emphasizes the importance of molecular studies in patients with craniosynostosis.

\section{Case Report}

The proband, a 1 year/3-month-old Mexican male, is the third child of healthy, unrelated and young (34 and 30-year-old) parents. Family history was negative for intellectual disability or congenital malformations. No history of prenatal exposure to teratogens or maternal illness was recorded. After an uneventful pregnancy, he was born by abdominal delivery at 37 weeks' gestation with a weight of $2,950 \mathrm{~g}(10-25$ th centile), a length of $51 \mathrm{~cm}$ (75th centile). OFC was not recorded. Apgar scores were 8 and 9 at 1 and $5 \mathrm{~min}$. He did not require special neonatal management. Dolichocephaly with craniosynostosis was detected at 2 months by the parents. At the age of 5 months, he underwent sagittal suterectomy which led to bleeding with hypovolemic shock and required a blood transfusion. Blood analyses showed normal platelet in numbers $(134,000)$ with 
medium platelet volume of $8.3 \mathrm{fl}(7.5-10 \mathrm{fl})$, all other blood test results were within normal parameters. On physical examination (at 1 year and 3 months), his weight was 9,200 $\mathrm{g}$ ( $3 \mathrm{rd}$ percentile), length was $76 \mathrm{~cm}$ (10-25 percentile), and the OFC was $46.5 \mathrm{~cm}(25-50$ percentile). He had trigonocephaly, eye exotropia, reverse epicanthic folds, narrow and high palate, broad nasal bridge, hypoplastic nares, thin upper lip, bilateral single palmar crease, valgus foot, overlapping of 1 st on the 2 nd toe in both feet, and right cryptorchidism (fig. 1). Audiological and ophthalmologic examinations were normal. The echocardiogram was normal. Blood analysis showed normal platelet in numbers $(167,000)$ with medium platelet volume of $11 \mathrm{fl}(7.5-10 \mathrm{fl})$; all other blood test results were in normal ranges. At this age, he underwent metopic suterectomy with profuse bleeding and hypovolemic shock which required a blood transfusion. Urine analyses and thyroid profile were normal.

CT scans of the brain showed cortico-subcortical atrophy, sagittal and metopic synostosis (fig. 2). At 9 months, the echocardiogram detected a mild tricuspid insufficiency. Currently, the boy needs assistance when standing up and only expresses some monosyllabic utterances.

\section{Material and Methods}

Metaphase slides were prepared from peripheral blood lymphocyte cultures from the patient and his parents, using standard methods. Chromosome analysis was performed by routine GTGbanding at $\sim 500$-band resolution.

Oligonucleotide-SNP array analysis using the GeneChip Human Cytoscan HD was carried out for the patient following the provided protocol (Affymetrix, Santa Clara, Calif., USA) and using the Affymetrix GeneChip Scanner 3000 7G. Data were analyzed using GTYPE (GeneChip Genotyping Analysis Software, 1.0.12 version) to detect copy number aberrations. The resolution of this procedure was estimated at $1.15 \mathrm{~kb}$ with 2.67 million probes.

\section{Results}

The proband's karyotype after GTG-banding was 46,XY,del(11)(q23q25) in 50 analyzed metaphases compatible with the diagnosis of JBS. Parental karyotypes were normal. The SNP array showed a 14.2-Mb deletion in chromosome 11q23.3q25 (120,706-134,938 Mb) which involved 163 RefSeq genes in the database of genomic variation, DGV database (http://projects.variation.tcag. $\mathrm{ca} /$ variation/hg38/); 62 genes are in the OMIM database (fig. 3), 8 of these genes (TECTA, SCN3B,CDON, ST3GAL4, KIRREL3, KCNJ5, ETS1, and NTM) have a heterozygous defect, and 13 genes have been associated to a recessive phenotype (SC5D, UBASH3B, CLMP, CHEK1, SLC37A2, FEZ1, HYLS1, STT3A, FOXRED1, KCNJ1, ST14, JAM3, and ACAD8). The final cytogenetic result was 46,XY,del(11)(q23.3q25), arr [hg38] 11q23.3q25 $(120,706,758-134,938,470) \times 1 \mathrm{dn}$.

Jacobsen Syndrome

\section{Discussion}

The diagnosis of our patient was JBS; clinically, our patient had mild motor delay, craniosynostosis, craniofacial dysmorphism, and a normal count and size of thrombocytes at 5 months of age. At 15 months of age, discretely larger thrombocytes, mild tricuspid insufficiency, cortico-subcortical atrophy, and cryptorchidism were observed. To date, 17 cases ranging in size from 2.8 to $14 \mathrm{Mb}$ with $11 \mathrm{q} 23.3 \mathrm{q} 25$ deletions revealed by molecular karyotyping and complete clinical data have been reported (table 1). These cases present craniofacial dysmorphism; developmental delay or intellectual disability; blood, growth and heart disorders, and brain defects similar to our case (table 1).

The 14.2 Mb-deletion of our patient includes 62 OMIM genes, 8 of them with a heterozygous expression pattern (table 2). Apparently, the platelet defect detected at 15 months, motor delay and mild tricuspid regurgitation could have a relationship with the ST3GAL4, KIRREL3 and ETS1 genes, respectively, although these findings are not always present in JBS with happloinsuficiency of these genes [Grewal et al., 2008; Ji et al., 2010; Bae et al., 2011; Luukkonen et al., 2012; Trkova et al., 2012; Sheth et al., 2014; So et al., 2014].

The principal genes involved in the Jacobsen phenotype seem to correspond to the ST3GAL4, KIRREL3, NFRKB, FL1, and ETS1 genes. The FLI1 gene, involved in the vascular and megakaryocyte differentiation, has been related to thrombocytopenia, although it has a recessive pattern [Spyropoulos et al., 2000; Trkova et al., 2012]. It is important to mention that the FLI1 gene defect is the major cause of Paris-Trousseau syndrome (PTS); in vitro studies demonstrate that overexpression of FLI1 in CD34(+) cells from PTS patients restores the megakaryopoiesis, indicating that FLI1 hemizygous deletion contributes to the PTS hematopoietic defects [Raslova et al., 2004; Favier et al., 2015]. The ETS1 and NFRKB genes have also been associated with thrombocytopenia, but there are no confirmatory studies. It is noteworthy that the ST3GAL4 gene associated with thrombocytopenia has not been mentioned in any previous study; we consider that thrombocytopenia could be related to this gene defect in JBS [Grossfeld et al., 2004]. However, not all cases with a deletion in the ST3GAL4 gene are diagnosed with thrombocytopenia [Ji et al., 2010; Trkova et al., 2012, Sheth et al., 2014; So et al., 2014]. This denotes that there is no genotype-phenotype correlation in JBS (table 1).

It is important to mention that the BSX1 gene could be essential for global cognitive function, and when haplo- 


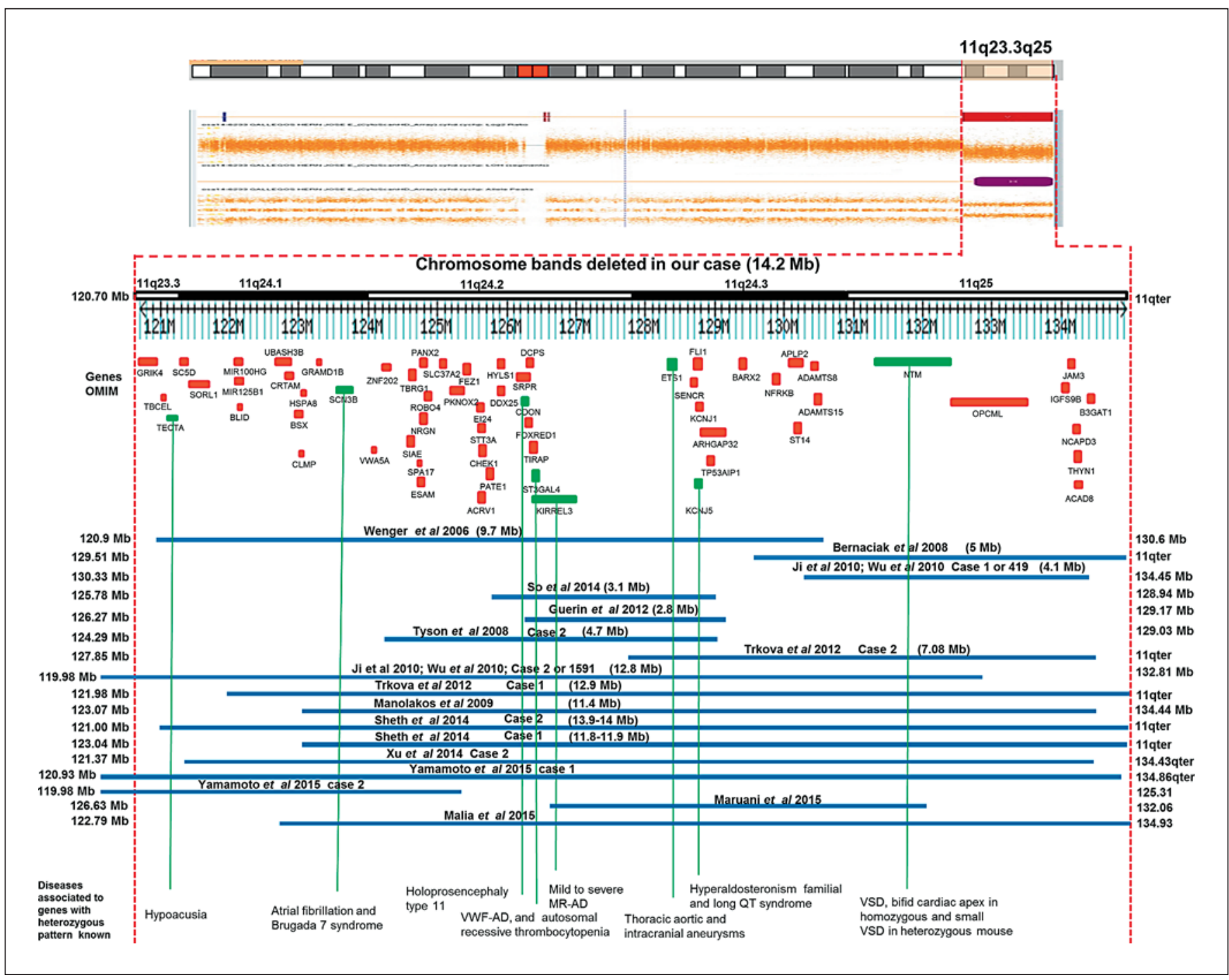

Fig. 3. CytoScan HD array and schematic representation of the result. The figure shows chromosome 11q23.3q25 and the relative position of the genes (TECTA, SCN3B, CDON, ST3GAL4, KIRREL3, KCNJ5, ETS1, and NTM) associated with heterozygous phenotypes (green) and the 13 genes (SC5D, UBASH3B, CLMP, CHEK1, SLC37A2, FEZ1, HYLS1, STT3A, FOXRED1, KCNJ1, ST14, JAM3, and $A C A D 8)$ associated with a phenotype with recessive manifes- tation in the deleted interval. The OMIM genes are shown in red. A partial molecular karyotype of the imbalance in chromosome 11 detected with the Human Cytoscan HD array is also illustrated. A single copy of the $14.2-\mathrm{Mb}$ region was identified by $\log _{2}$ ratio, copy number state and allele analysis. Some affected patients with deletion in the $11 \mathrm{q} 23.3 \mathrm{q} 25$ region are also shown. insufficiency of $B S X 1$ is present, this could result in severe mental retardation. In addition, a deletion of neurogranin, a gene essential for synaptic plasticity and longterm potentiation, participates in the auditory attention deficit in most patients with 11q deletion [Coldren et al., 2009].

On the other hand, a previous report states that there is no correlation between the deletion size of $11 \mathrm{q}$ and the presence of autism, implicating a critical region in 11q, that includes the RICS, a gene encoding Rho GTPase-activating protein [Akshoomoff et al., 2015].

We consider that some genes, e.g. KCNJ5 or $S C N 3 B$, have a negative dominant effect [Wang et al., 2010; Yang et al., 2010]; this leads to a mild or null defect in the phenotype. Nevertheless, it is important to take into account the effects of haploinsufficiency of all affected genes in the 
Table 1. Comparison of clinical features in 17 cases of 11q23q25 deletion with molecular karyotyping

\begin{tabular}{|c|c|c|c|c|c|c|c|c|c|}
\hline Reference & $\begin{array}{l}\text { Growth/motor } \\
\text { or intellectual } \\
\text { delay }^{\mathrm{a}}\end{array}$ & $\begin{array}{l}\text { Craniofacial } \\
\text { dysmorphism }^{\text {b }}\end{array}$ & Blood $^{c}$ & Heart $^{\mathrm{d}}$ & $\begin{array}{l}\text { Neurology } \\
\text { disorder/brain } \\
\text { image }^{\mathrm{e}}\end{array}$ & $\begin{array}{l}\text { Other } \\
\text { characteristics }^{f}\end{array}$ & $\begin{array}{l}\text { Size } \\
\text { deleted, } \\
\mathrm{Mb}\end{array}$ & $\begin{array}{l}\text { Molecular } \\
\text { karyo- } \\
\text { typing }\end{array}$ & Sex/age \\
\hline $\begin{array}{l}\text { Present } \\
\text { case }\end{array}$ & $+/+$ & + & $\begin{array}{l}\text { bleeding at } 5 \mathrm{~m} \text { by } \\
\text { cranioplasty, } \\
\text { borderline upper } \\
\text { platelet at } 8 \mathrm{~m}\end{array}$ & $\begin{array}{l}\text { mild tricuspid } \\
\text { insufficiency }\end{array}$ & $\begin{array}{l}\text { cortico-subcor- } \\
\text { tical atrophy }\end{array}$ & cryptorchidism & 14.2 & SNP array & F/1 year \\
\hline $\begin{array}{l}\text { Wenger et } \\
\text { al., } 2006\end{array}$ & $+/+$ & + & $\begin{array}{l}\text { thrombocytopenia at } \\
\text { birth and } 3 \mathrm{~m} \text {, } \\
\text { atypical megakaryo- } \\
\text { cytes at } 3 \mathrm{~m}\end{array}$ & $\begin{array}{l}\text { ADS, PDA, } \\
\text { PAS, double } \\
\text { outlet right } \\
\text { ventricle }\end{array}$ & $\begin{array}{l}\text { no expressive } \\
\text { language at } 2 \mathrm{y}\end{array}$ & exotropia, ptosis & 9.7 & BAC array & $\mathrm{F} / 2$ years \\
\hline $\begin{array}{l}\text { Bernaciak } \\
\text { et al., } 2008\end{array}$ & $-1+$ &,+ mild & - & - & $\begin{array}{l}\text { hyperintense } \\
\text { white matter, } \\
\text { hyperactivity, } \\
\text { aggressiveness, } \\
\text { pain indiffe- } \\
\text { rence }\end{array}$ & - & 5.4 & $\mathrm{aCGH}$ & $\mathrm{F} / 4$ years \\
\hline \multicolumn{10}{|l|}{$\begin{array}{l}\text { Tyson et al., } \\
2008\end{array}$} \\
\hline Case 2 & $-1+$ & + & anemia & - & $\begin{array}{l}\text { speech delay, } \\
\text { white matter } \\
\text { lesions }\end{array}$ & $\begin{array}{l}\text { mild bilateral } \\
\text { hearing loss }\end{array}$ & 4.7 & $\mathrm{aCGH}$ & M/7 years \\
\hline $\begin{array}{l}\text { Manolakos } \\
\text { et al., } 2009\end{array}$ & $-1-$ &,+ mild & $\begin{array}{l}\text { anemia, platelet } \\
\text { aggregation and } \\
\text { bleeding time } \\
\text { abnormal }\end{array}$ & $\begin{array}{l}\text { mitral valve } \\
\text { regurgitation }\end{array}$ & $\begin{array}{l}\text { speech delay, } \\
\text { hypotonic }\end{array}$ & $\begin{array}{l}\text { mild bilateral } \\
\text { hearing loss, } \\
5 \text { th finger short }\end{array}$ & 11.4 & SNP array & $\mathrm{M} / 7.5$ years \\
\hline $\begin{array}{l}\text { Guerin } \\
\text { et al., } 2012\end{array}$ & $-1+$ &,+ mild & $\begin{array}{l}\text { anemia, at } 4 \mathrm{~m} \\
\text { thrombocytopenia } \\
\text { spontaneous } \\
\text { resolution, platelet } \\
\text { ATP and dense } \\
\text { granules decreased, } \\
\text { giant granules present }\end{array}$ & VSD & ASD & - & 2.8 & $\mathrm{aCGH}$ & $\mathrm{F} / 4$ years \\
\hline
\end{tabular}

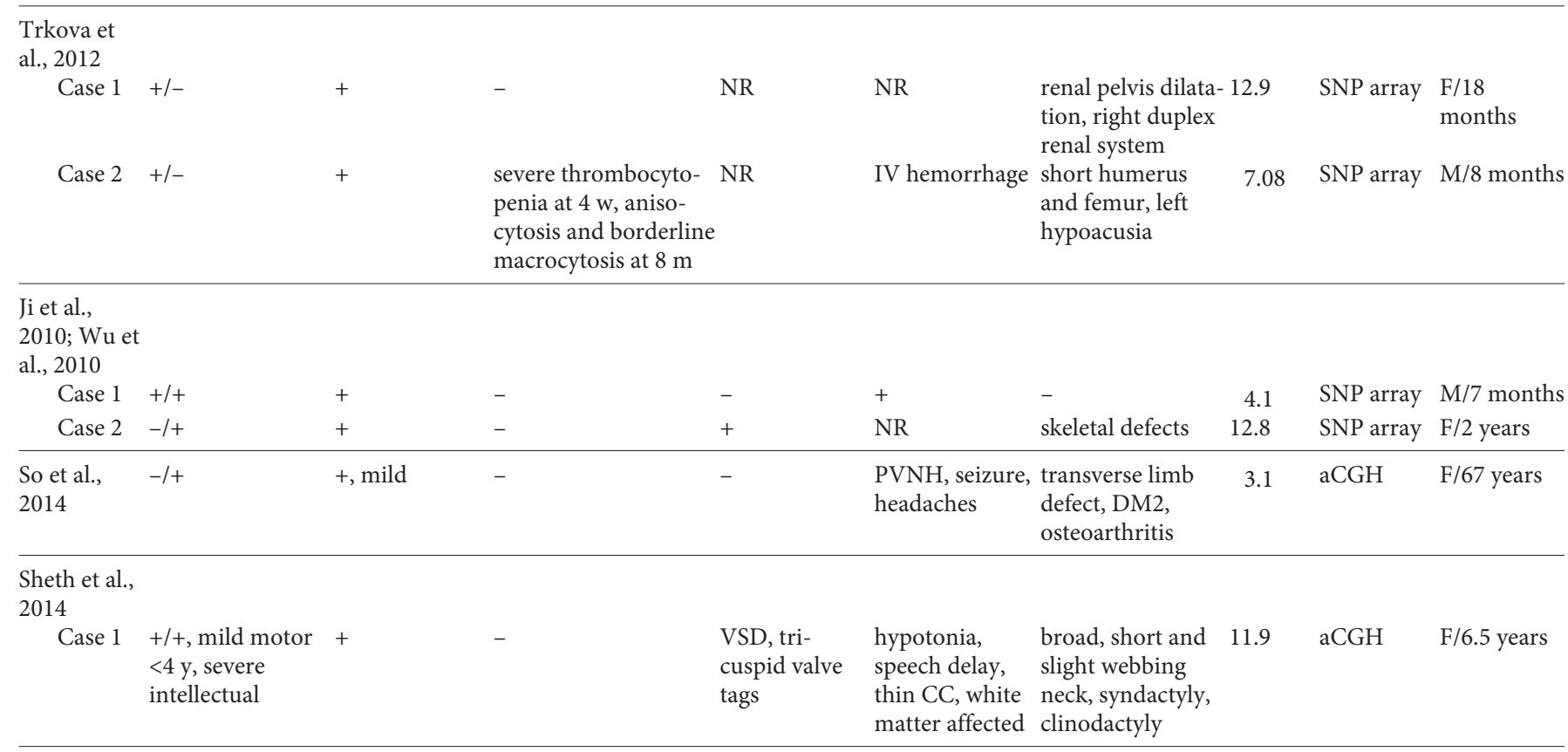


Table 1 (continued)

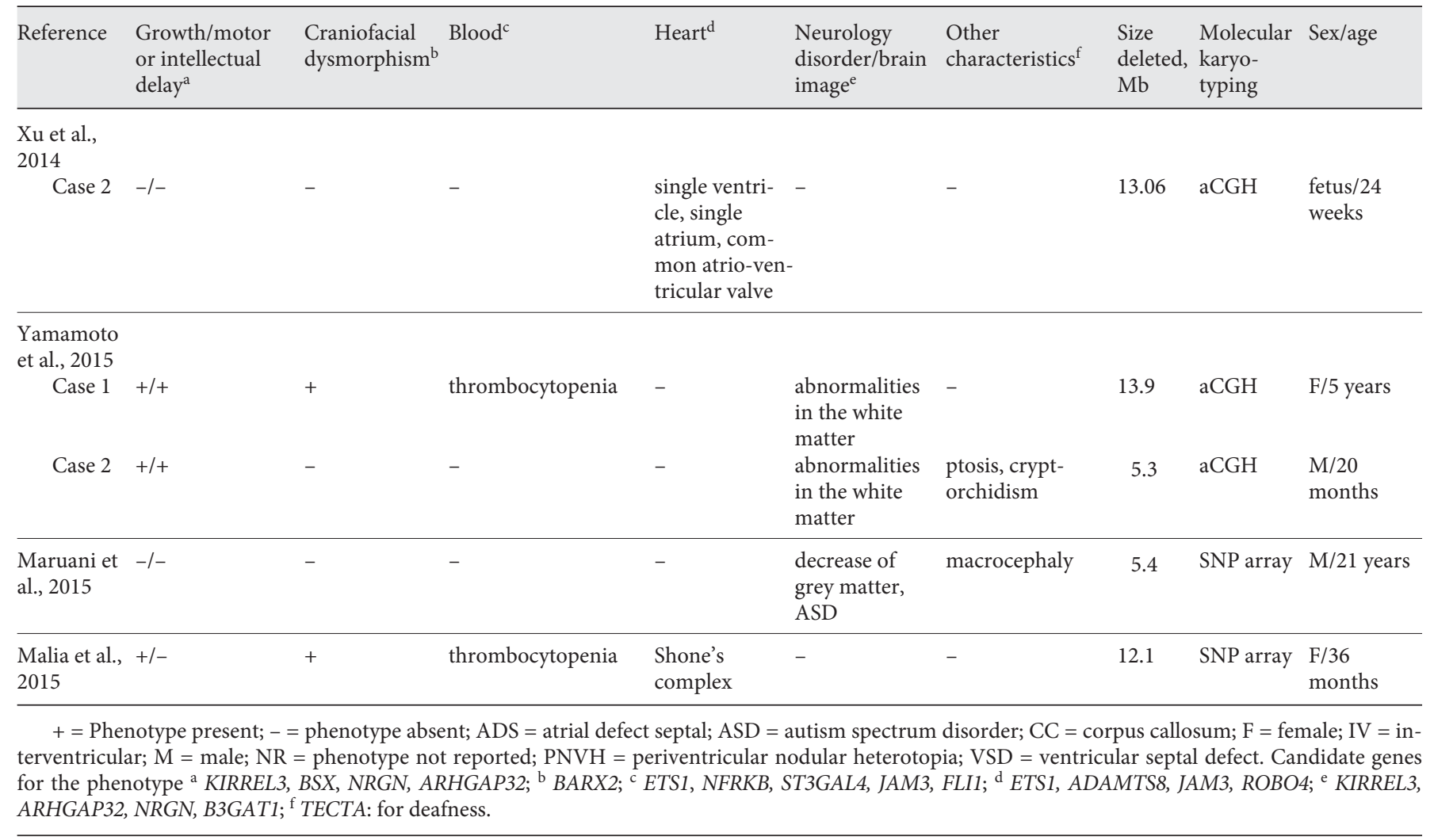

Table 2. Heterozygous gene defect in the deleted region 11q23.3q25

\begin{tabular}{|c|c|c|c|c|}
\hline OMIM & Gene & Disease & Inheritance & Dosis \\
\hline 602574 & TECTA & deafness & $\mathrm{AD} / \mathrm{AR}$ & haploinsufficiency \\
\hline 608214 & $S C N 3 B$ & atrial fibrillation and Brugada 7 syndrome & $\mathrm{AD}$ & $\begin{array}{l}\text { dominant negative/ } \\
\text { haploinsufficiency }\end{array}$ \\
\hline 608707 & CDON & holoprosencephaly type 11 & $\mathrm{AD}$ & haploinsufficiency \\
\hline 104240 & ST3GAL4 & $\begin{array}{l}\text { reduction in plasma levels of von Willebrand factor and } \\
\text { platelets/thrombocytopenia }\end{array}$ & $\mathrm{AD} / \mathrm{AR}$ & haploinsufficiency \\
\hline 607761 & KIRREL3 & mental retardation & $\mathrm{AD}$ & haploinsufficiency \\
\hline 600734 & KCNJ5 & hyperaldosteronism familial and long QT syndrome & $\mathrm{AD}$ & $\begin{array}{l}\text { dominant negative/ } \\
\text { haploinsufficiency }\end{array}$ \\
\hline 607938 & NTM & thoracic aortic and intracranial aneurysms & $\mathrm{AD}$ & haploinsufficiency \\
\hline 164720 & ETS1 & small ventricular septal defect in mouse & $\mathrm{AD}$ & haploinsufficiency \\
\hline
\end{tabular}

$\mathrm{AD}=$ Autosomal dominant; $\mathrm{AR}=$ autosomal recessive.

phenotype as well as the presence of the epigenetic or environmental factors.

Our patient underwent surgery with severe complications (profuse bleeding) because JBS never was diagnosed. His surgery was necessary because of simple craniosynostosis, and this marks the importance of a genetic evaluation and meticulous medical semiology. Besides, it is very important to delineate the size of deletion of pa- tients with JBS using current molecular techniques. This will allow us to understand the genetic and clinical variability of the $11 \mathrm{q}$ phenotype.

In conclusion, the large variability in the breakpoints in $11 \mathrm{q} 23 \mathrm{q} 25$ syndrome indicates the complexity of the JBS phenotype. In addition, an adequate medical evaluation is compulsory to avoid surgery complications. 


\section{Statement of Ethics}

The protocol was approved by the Ethics Committee of the General Hospital of Mexico. Informed consent was obtained from the parents of the patient prior to the participation in the study.

\section{Disclosure Statement}

The authors have no conflict of interest to declare.

\section{References}

Akshoomoff N, Mattson SN, Grossfeld PD: Evidence for autism spectrum disorder in Jacobsen syndrome: identification of a candidate gene in distal 11q. Genet Med 17:143-148 (2015).

Bae GU, Domené S, Roessler E, Schachter K, Kang JS, et al: Mutations in CDON, encoding a hedgehog receptor, result in holoprosencephaly and defective interactions with other hedgehog receptors. Am J Hum Genet 89: 231-230 (2011).

Bernaciak J, Szczałuba K, Derwińska K, Wiśniowiecka-Kowalnik B, Bocian E, et al: Clinical and molecular-cytogenetic evaluation of a family with partial Jacobsen syndrome without thrombocytopenia caused by an approximately $5 \mathrm{Mb}$ deletion $\operatorname{del}(11)$ (q24.3). Am J Med Genet A 146A:2449-2454 (2008).

- Coldren CD, Lai Z, Shragg P, Rossi E, Glidewell $\mathrm{SC}$, et al: Chromosomal microarray mapping suggests a role for BSX and Neurogranin in neurocognitive and behavioral defects in the $11 \mathrm{q}$ terminal deletion disorder (Jacobsen syndrome). Neurogenetics 10:89-95 (2009).

- Favier R, Akshoomoff N, Mattson S, Grossfeld P: Jacobsen syndrome: advances in our knowledge of phenotype and genotype. Am J Med Genet C Semin Med Genet 169:239-250 (2015).

Grewal PK, Uchiyama S, Ditto D, Varki N, Le DT, et al: The Ashwell receptor mitigates the lethal coagulopathy of sepsis. Nat Med 14:648-655 (2008).

Grossfeld PD, Mattina T, Lai Z, Favier R, Jones $\mathrm{KL}$, et al: The $11 \mathrm{q}$ terminal deletion disorder: a prospective study of 110 cases. Am J Med Genet A 129A:51-61 (2004).

- Guerin A, Stavropoulos DJ, Diab Y, Chénier S, Christensen $\mathrm{H}$, et al: Interstitial deletion of 11q-implicating the KIRREL3 gene in the neurocognitive delay associated with Jacobsen syndrome. Am J Med Genet A 158A:25512556 (2012).

$\checkmark$ Ji T, Wu Y, Wang H, Wang J, Jiang Y: Diagnosis and fine mapping of a deletion in distal 11q in two Chinese patients with developmental delay. J Hum Genet 55:486-489 (2010).

Luukkonen TM, Pöyhönen M, Palotie A, Ellonen $\mathrm{P}$, Lagström S, et al: A balanced translocation truncates Neurotrimin in a family with intracranial and thoracic aortic aneurysm. J Med Genet 49:621-629 (2012).
Malia LA, Wolkoff LI, Mnayer L, Tucker JW, Parikh NS: A case report: Jacobsen syndrome complicated by Paris-Trousseau syndrome and Shone's complex. J Pediatr Hematol Oncol 37:e429-432 (2015).

Manolakos E, Orru S, Neroutsou R, Kefalas K, Louizou E, et al: Detailed molecular and clinical investigation of a child with a partial deletion of chromosome 11 (Jacobsen syndrome). Mol Cytogenet 2:26 (2009).

-Maruani A, Huguet G, Beggiato A, ElMaleh M, Toro $\mathrm{R}$, et al: 11q24.2-25 micro-rearrangements in autism spectrum disorders: relation to brain structures. Am J Med Genet A (2015), E-pub ahead of print.

Mattina T, Perrotta CS, Grossfeld P: Jacobsen syndrome. Orphanet J Rare Dis 4:9 (2009).

-Raslova H, Komura E, Le Couédic JP, Larbret F, Debili N, et al: FLI1 monoallelic expression combined with its hemizygous loss underlies Paris-Trousseau/ Jacobsen thrombopenia. J Clin Invest 114:77-84 (2004).

Seppänen M, Koillinen H, Mustjoki S, Tomi M, Sullivan KE: Terminal deletion of $11 \mathrm{q}$ with significant late-onset combined immune deficiency. J Clin Immunol 34:114-118 (2014).

Sheth FJ, Datar C, Andrieux J, Pandit A, Nayak D, et al: Distal deletion of chromosome 11q encompassing Jacobsen syndrome without platelet abnormality. Clin Med Insights Pediatr 8:45-49 (2014).

So J, Stockley T, Stavropoulos DJ: Periventricular nodular heterotopia and transverse limb reduction defect in a woman with interstitial 11q24 deletion in the Jacobsen syndrome region. Am J Med Genet A 164A:511-515 (2014).

Spyropoulos DD, Pharr PN, Lavenburg KR, Jackers P, Papas TS, et al: Hemorrhage, impaired hematopoiesis, and lethality in mouse embryos carrying a targeted disruption of the Fli1 transcription factor. Mol Cell Biol 20:56435652 (2000).

Trkova M, Becvarova V, Hynek M, Hnykova L, Hlavova E, et al: SNP array and phenotype correlation shows that FLI1 deletion per se is not responsible for thrombocytopenia development in Jacobsen syndrome. Am J Med Genet A 158A:2545-2550 (2012).
Tyson C, Qiao Y, Harvard C, Liu X, Bernier FP, et al: Submicroscopic deletions of 11q24-25 in individuals without Jacobsen syndrome: reexamination of the critical region by high-resolution array-CGH. Mol Cytogenet 1:23 (2008).

Van Zutven LJ, van Bever Y, Van Nieuwland CC, Huijbregts GC, Van Opstal D, et al: Interstitial 11q deletion derived from a maternal ins(4; 11)(p14;q24.2q25): a patient report and review. Am J Med Genet A 149A:1468-1475 (2009).

Wang P, Yang Q, Wu X, Yang Y, Shi L, et al: Functional dominant-negative mutation of sodium channel subunit gene $S C N 3 B$ associated with atrial fibrillation in a Chinese GeneID population. Biochem Biophys Res Commun 398:98-104 (2010).

-Wenger SL, Grossfeld PD, Siu BL, Coad JE, Keller FG, Hummel M: Molecular characterization of an 11q interstitial deletion in a patient with the clinical features of Jacobsen syndrome. Am J Med Genet A 140:704-708 (2006).

Wu Y, Ji T, Wang J, Xiao J, Wang H, et al: Submicroscopic subtelomeric aberrations in Chinese patients with unexplained developmental delay/mental retardation. BMC Med Genet 11:72 (2010).

Xu Z, Geng Q, Luo F, Xu F, Li P, Xie J: Multiplex ligation-dependent probe amplification and array comparative genomic hybridization analyses for prenatal diagnosis of cytogenomic abnormalities. Mol Cytogenet 7:84 (2014).

Yamamoto T, Shimada S, Shimojima K, Sangu N, Ninomiya S, Kubota M: Leukoencephalopathy associated with 11q24 deletion involving the gene encoding hepatic and glial cell adhesion molecule in two patients. Eur J Med Genet 58:492-496 (2015).

Yang Y, Yang Y, Liang B, Liu J, Li J, et al: Identification of a Kir3.4 mutation in congenital long QT syndrome. Am J Hum Genet 86:872880 (2010).

Ye M, Coldren C, Liang X, Mattina T, Goldmuntz E, et al: Deletion of ETS-1, a gene in the Jacobsen syndrome critical region, causes ventricular septal defects and abnormal ventricular morphology in mice. Hum Mol Genet 19: 648-656 (2010). 